\title{
REAPPRAISAL OF EXPERIMENTAL INFECTIONS WITH CERCARIAE AND SCHISTOSOMULA OF A BRAZILIAN STRAIN OF Schistosoma mansoni IN MICE
}

\author{
VILAR, M. M. ${ }^{1}$ and PINTO, R. M. ${ }^{2}$ \\ ${ }^{1}$ Laboratório de Esquistossomose Experimental \\ ${ }^{2}$ Laboratório de Helmintos Parasitos de Vertebrados, Departamento de Helmintologia, Instituto Oswaldo Cruz, \\ Fiocruz, Av. Brasil, 4365, CEP 21040-900, Rio de Janeiro, RJ, Brazil \\ Correspondence to: Roberto Magalhães Pinto, Laboratório de Helmintos Parasitos de Vertebrados, \\ Departamento de Helmintologia, Instituto Oswaldo Cruz, Av. Brasil, 4365, CEP 21040-900, \\ Rio de Janeiro, RJ, Brazil, e-mail: rmpinto@ioc.fiocruz.br
}

Received October 7, 2004 - Accepted November 11, 2004 - Distributed November 30, 2005

(With 1 Figure)

\begin{abstract}
The present investigation involves a reevaluation of previous results obtained after experimental infection of Swiss Webster mice with cercariae and schistosomula of the Schistosoma mansoni LE strain maintained under laboratory conditions. Three experimental groups of mice were considered: the animals of the first group were percutaneously (ring method) infected with cercariae, those of the second were subcutaneously inoculated with cercariae and the mice of the third were inoculated by the same route with schistosomula transformed in vitro. The data obtained so far indicated that the most effective method of infection is the subcutaneous injection with schistosomula, with a mean adult worm burden recovery of $54.1 \%$ when compared to the abdominal percutaneous and subcutaneous routes of infection with cercariae, in which the values were $36.7 \%$ and $32.4 \%$, respectively. This suggests that, in experimental infections of SW mice with a LE S. mansoni strain, the skin is to be considered an effective attrition site in the percutaneous route, whereas in the case of inoculation with cercariae, a small amount of larvae fails to be transformed into viable schistosomula, possibly due to skin phase avoidance. A brief discussion about attrition sites and elimination of larval $S$. mansoni worms in mice is presented.
\end{abstract}

Keywords: S. mansoni, cercariae, schistosomula, experimental infections, mice.

\section{RESUMO}

\section{Reavaliação de infecções experimentais em camundongos com uma cepa brasileira de Schistosoma mansoni}

Os objetivos da presente investigação foram os de reavaliar resultados anteriores obtidos através de infecções experimentais de camundongos SW com cercarias e esquistossômulos da cepa LE de Schistosoma mansoni mantida em laboratório. Três grupos de camundongos foram considerados: animais do primeiro grupo foram infectados com cercarias pela via percutânea (método do anel), os do segundo inoculados pela via subcutânea com cercarias e os do terceiro inoculados pela mesma via com esquistossômulos obtidos "in vitro". Os dados obtidos mostraram que a via de infecção mais eficiente é a injeção subcutânea de esquistossômulos transformados "in vitro", com média de recuperação de vermes adultos de $54.1 \%$, quando comparada às vias percutânea abdominal e subcutânea, com médias de 36,7\% e 32,4\%, respectivamente, sugerindo que em infecções experimentais de camundongos SW com S. mansoni da cepa LE, a pele pode ser considerada um eficaz sítio de atrito na via percutânea, enquanto no caso da inoculação de cercarias, um pequeno número de larvas não se transforma em esquistossômulos viáveis, talvez pelo fato de a barreira da pele haver sido evitada. Breves considerações a respeito dos sítios de atrito e eliminação de formas larvares do S. mansoni em camundongos, são apresentadas.

Palavras-chave: S. mansoni, cercarias, esquistossômulos, infeccções experimentais, camundongos. 


\section{INTRODUCTION}

The efficacy of different experimental routes of infection by Schistosoma mansoni in mice was previously analyzed in order to properly quantify adult worm burdens in these hosts. The patterns of infection and migration of $S$. mansoni by different routes in mice and other permissive hosts often refer to either naive or vaccinated animals, since this parameter must be taken into account to properly evaluate different biological assays in experimental schistosomiasis. In Brazil, reports considering this aspect are those of Holanda et al. (1974), Tendler et al. (1985), Pinto et al. (1987, 1990, 1994), in which different routes of infection with S. mansoni and migration patterns are discussed.

The aims of the present investigation are to reevaluate the results on the recovery of $S$. mansoni adult worms after experimental infection of Swiss Webster mice inoculated with schistosomula of $S$. mansoni LE strain, transformed in vitro, thus avoiding the first cercarial attrition that occurs during the skin phase following percutaneous infections.

\section{MATERIALS AND METHODS}

Cercariae - Forty Biomphalaria glabrata snails infected with a $S$. mansoni LE strain were kept in $200 \mathrm{~mL}$ of distilled water and exposed to artificial light during $2 \mathrm{~h}$ for the shedding of cercariae. The cercariae present in three aliquots of $0.2 \mathrm{~mL} /$ each of the solution and inactivated by Lugol's iodide were then counted three times under a stereoscopic microscope to ascertain the total number of cercarie in the solution and adjust the number necessary in each step of the experiment. Some of the cercarie were used to infect mice by the subcutaneous and percutaneous routes.

In vitro schistosomula - Briefly, cercarial solution was reduced to a volume of $10 \mathrm{~mL}$ of 30,000 cercarie/ml, put on ice for $10 \mathrm{~min}$ for deposition, and then packed by 45 " low-speed centrifugation. The supernatant was removed and the larvae were suspended in $6 \mathrm{~mL}$ of TC medium RPMI \# 1640 (Difco ${ }^{\circledR}$ ) and centrifuged for 45 " in a mixer for tail loss; this procedure was repeated three times. The cercariae were then kept for 40' at room temperature $\left(30^{\circ} \mathrm{C}\right)$ to induce secretion and finally incubated for $1 \mathrm{~h}$ at $37{ }^{\circ} \mathrm{C}$ for coat removal. From the solution of newly transformed schistosomula, an aliquot of $0.01 \mathrm{~mL}$ was used to count the larvae and adjust the number to be administered to mice, similarly to the procedure adopted for quantifying the cercariae.

Animals and infection procedures Thirty male Swiss Webster mice from the Instituto Oswaldo Cruz central animal house (CECAL), weighing $25 \mathrm{~g}$, age 4 weeks, were divided into three groups of 10 mice each and the groups were named A, B and C. The mice in group A were percutaneously infected with 100 cercariae/animal following a procedure adapted from the ring method (Tendler \& Pinto, 1981), the mice of group B were injected subcutaneously with 100 schistosomula/animal and the mice of group $\mathrm{C}$ were also injected subcutaneously with 100 cercariae/animal. The subcutaneous injections were administered according to the technique described by Peters \& Warren (1969).

Adult worms - Adult worms were recovered from A, B, and C 45 days after the animals' experimental infection by means of perfusion of hepatic and mesenteric veins, according to the method of Pellegrino \& Siqueira (1956).

Statistical analysis - The data were treated in accordance with Gomes (1987) and Serra-Freire's description (2002).

\section{RESULTS}

The mean adult worm recovery in group A was $36.7 \%$ of the infective burden; in group B the recovery was $54.1 \%$ and in group $\mathrm{C}$ it was $32.4 \%$ (Fig. 1), with standard errors of 1.5, 2.2 and 0.7, respectively, in accordance with each analyzed group.

The number of adult S. mansoni worms recovered from mice after inoculation with schistosomula (28-86) varied more than from mice infected percutaneously (20-27) or from those infected subcutaneously with cercariae (20-42). In an interval of $65 \%$ of confidence for the analyzed population, the smallest worm burden size (28) recovered from mice inoculated with schistosomula (group B) was technically the same as the largest size (42) yielded by mice injected with cercariae (group C) and close to the smallest size (20) obtained from mice exposed to cercariae by the percutaneous infection route (group A). Considering that the asymmetry of the size of worm burdens from mice of group B was positive and 


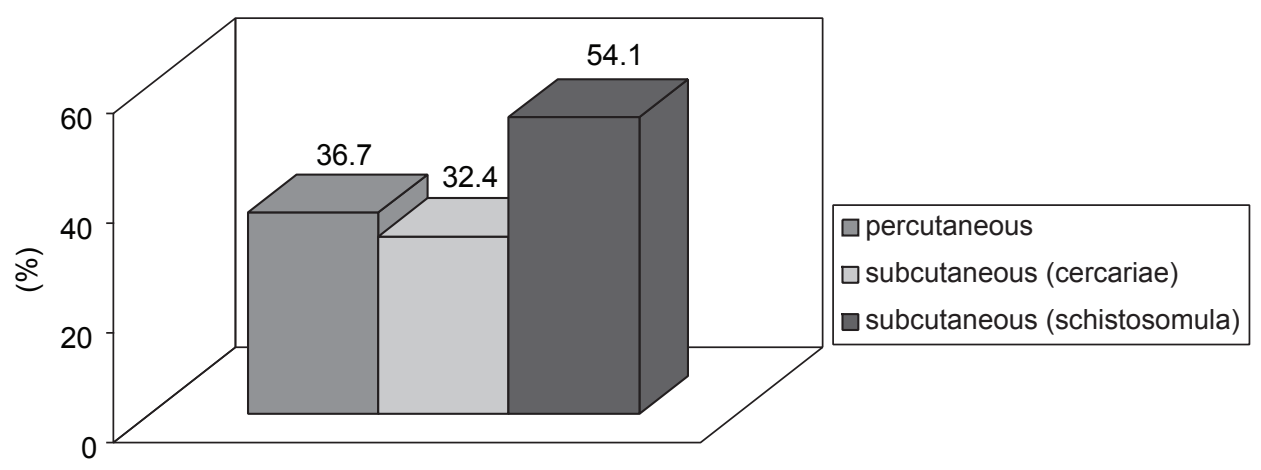

Fig. 1 - Recovery pattern of Schistosoma mansoni adult worms 45 days after experimental infection of SW mice with cercariae administered by subcutaneous and percutaneous routes, with schistosomula obtained in vitro and injected subcutaneously.

with a low inclination (As $=0.310$ ), these results are of external validity, suggesting a populational behavior, with an error probability of $5 \%$.

\section{DISCUSSION}

Final results of experimental assays to evaluate the protective activity of different antigens against schistosomiasis are based mostly on the reduction of worm burdens in vaccinated animals compared to unprimed controls.

The early recovery of larval parasite loads of S. mansoni either from the skin or from the lungs has been frequently reported worldwide in an attempt to shorten experiments in which this protection is being tested. However, together with antigenically induced responses, much has been discussed about the temporal distribution of schistosomula and parasite attrition sites where death of schistosomula occurs, with a natural decrease of adult worms in the definitive mammalian host (Pinto et al., 1987, 1990, 1994; Coulson \& Mountford, 1989; Dean \& Mangold, 1992).

In SW mice infected subcutaneously with S. mansoni cercariae, about $70 \%$ of the larval forms are destroyed before reaching maturity as adult worms (Holanda et al., 1974, Tendler et al., 1985). Data on the attrition of larval S. mansoni in mice and other suitable hosts have been widely reported. It is known that death of young worms can occur in the skin, lungs and liver; however, the pattern of parasite destruction in these sites is not yet definitively established and seems to depend on the route of infection, and the parasite and host strains.
Tracking the migration of ${ }^{75} \mathrm{Se}$-methionine labeled LE strain cercariae of $S$. mansoni in unprimed SW mice by means of autoradiographic analysis, Pinto et al. (1987) showed that 50\% of the cercariae administered percutaneously (ring method) to the animals were detected in the lungs 4 days after infection, when peak accumulation of schistosomula occurred. Conversely, when cercariae were inoculated, $50 \%$ were present in the lungs 4 days after infection, but the peak accumulation was detected on day 6 , with an extra amount of $20 \%$ of the infecting larvae present in that site, demonstrating that $70 \%$ of the larval forms reach the lung phase in percutaneous infections via abdominal skin.

In their analysis of the extent of attrition of a Puerto Rican strain of $S$. mansoni in naïve C57BL/6 J mice, Mangold \& Dean (1983) found a loss of no more than $20 \%$ of the infecting cecariae during the skin phase after percutaneous infection (tail immersion).

Dean \& Mangold (1984) reported evidence that the liver could be a major site of $S$. mansoni elimination; their findings were based on percutaneous infections (tail immersion) of NMRI mice with a Puerto Rican-derived strain of $S$. mansoni cercariae, showing that there appeared to be little loss of young schistosomula in the skin, if any elimination occurred, since nearly all the schistosomula detectable in the skin on day 1 had migrated to the lungs by day 6 .

Later, based on autoradiography, Dean \& Mangold (1992) indicated that normal elimination of $S$. mansoni takes place in the lung stage 
of migration. Their data were obtained after percutaneous infection (tail immersion) and intravenous injection of heat-killed schistosomula in $\mathrm{C} 57 \mathrm{Bl} / 6 \mathrm{~J}$ mice with a Puerto Rican strain of cercariae, so as to compare the fate of live and dead S. mansoni larval forms. The results showed that schistosomula (alive and dead) do not proceed beyond the lung stage of migration prior to parasite death.

The present results showed that, in mice injected with schistosomula, $45.6 \%$ of the larvae were killed before maturity and that 63.3 and $67.6 \%$ were destroyed during percutaneous and subcutaneous infections, respectively.

The fact that mice infected with inoculated schistosomula or exposed to cercariae by the percutaneous abdominal route yield a greater number of adult worms indicates that skin attrition seems to promote, similarly, the transformation of a greater number of cercariae into viable schistosomula. Thus, when in vitro transformed schistosomula are inoculated or cercariae are administered by the abdominal percutaneous route, the overall amount of adult worms recovered is larger.

In view of the controversial data on the migration of $S$. mansoni in mice, a proper understanding of the mechanisms of worm destruction in the different attrition sites would shed light on most aspects relating to the host's natural resistance to infection with $S$. mansoni when compared with the protection levels induced by immunizing agents.

The present results were analyzed together with those obtained by Holanda et al. (1974) and Tendler et al. (1985) from the infection of unprimed mice with schistosomula and cercariae of $S$. mansoni, respectively, with the same mice (SW) and cercariae (LE) strains utilized herein.

Those two earlier experiments provide important information about the patterns of infection of $S$. mansoni by endovenous, subcutaneous and percutaneous routes. Nevertheless, Holanda et al. (1974) did not investigate infection with cercariae by the percutaneous route, nor were schistosomula administered to the mice by Tendler et al., (1985). Those earlier results showed that the routes of infection used by both Holanda et al., (1974) and Tendler et al. (1985) presented constant patterns of worm recovery insofar as the inoculation of either cercariae or schistosomula, and abdominal percutaneous infection of SW mice with LE cercariae is concerned.

The present data confirm the results obtained through the injection of cercariae and schistosomula (Holanda et al., 1974) and those obtained from the comparative evaluation of the different experimental S. mansoni infection routes (Tendler et al., 1985).

Even considering that the transformation of schistosomula in vitro requires more complex procedures for their subsequent inoculation in suitable hosts, it is undoubtedly a more effective method than abdominal percutaneous infection, considering that inoculation is a rapid and accurate method for experimental infections with $S$. mansoni aimed at the recovery of uniform sizes of adult worm burdens.

Acknowledgments - To Conselho Nacional de Desenvolvimento Científico e Tecnológico (CNPq), Brazil, for partial financial support to R. M. Pinto; to Dr Nicolau Maués da Serra Freire, Laboratory of Ixodides, Department of Entomology, Oswaldo Cruz Institute for the statistical analysis of the results.

\section{REFERENCES}

COULSON, P. S. \& MOUNTFORD, A. P., 1989, Fate of attenuated schistosomula administered to mice by different routes, relative to the immunity induced against Schistosoma mansoni. Parasitology 99: 39-45.

DEAN, D. A. \& MANGOLD, B. L., 1984, Autoradioradiographic analysis of resistance to reinfection with Schistosoma mansoni in mice. Evidence that the liver is a major site of worm elimination. Am. J. Trop. Med. Hyg. 33: 97-103.

DEAN, D. A. \& MANGOLD, B. L., 1992, Evidence that both normal and immune elimination of Schistosoma mansoni take place at the lung stage of migration prior to parasite death. Amer. J. Trop. Med. Hyg. 47: 238-248.

GOMES, F. P., 1987, Curso de estatística experimental. NOBEL, São Paulo, 467 p.

HOLANDA, J. C., PELLEGRINO, J. \& GAZZINELLI, G., 1974, Infection of mice with cercariae and schistosomula of Schistosoma mansoni by intravenous and subcutaneous route. Rev. Inst. Med. trop. São Paulo 16: 132-134.

MANGOLD, B. L. \& DEAN, D. A., 1983, Autoradiographic analysis of Schistosoma mansoni migration from skin to lungs in naïve mice. Evidence that most attrition occurs after the skin phase. Am. J. Trop. Med. Hyg. 32: 785-789.

PELlEGRINO, J. \& SIQUEIRA, A. F., 1956, Técnica de perfusão para colheita de Schistosoma mansoni em cobaias experimentalmente infestadas. Rev. Brasil. Malariol. 8: 589-597.

PETERS, P. A. \& WARREN, K. S., 1969, A rapid method of infecting mice and other laboratory animals with 
Schistosoma mansoni: subcutaneous injection. J. Parasitol. 55: 558.

PINTO, R. M., NORONHA, D., ALMEIDA, M. S. S., TENDLER, M., KATZ, N. \& PALMA, S. S., 1987, Schistosoma mansoni: migration patterns in normal and immunized Swiss Webster mice, by means of autoradiographic analysis. Mem. Inst. Oswaldo Cruz, 82 (Suppl. IV): 231-232.

PINTO, R. M., ALMEIDA, M. S. S., NORONHA, D., KATZ, N. \& TENDLER, M., 1990, Autoradiographic analysis of Schistosoma mansoni migration in the NZ rabbit. Mem. Inst. Oswaldo Cruz, 85: 91-94.

PINTO, R. M., NORONHA, D., ALMEIDA, M. S. S., KATZ, N. \& TENDLER, M., 1994, Migration of Schistosoma mansoni Sambon (Trematoda, Schistosomatidae) from skin to lungs in immunized NZ rabbits (Lagomorpha, Leporidae) by means of autoradiographic analysis. Rev. bras. Zool. 11: 629-634.

SERRA-FREIRE, N. M., 2002, Planejamento e análise de pesquisas parasitológicas. EDUFF, Niterói, 199 p.

TENDLER, M. \& PINTO, R. M., 1981, A simple device to immobilize mice for infection with Schistosoma mansoni cercariae. J. Parasitol. 67: 583-584.

TENDLER, M., PINTO, R. M., CÔRTES, M. \& GEBARA, G., 1985, Schistosoma mansoni: comparative evaluation of different routes of experimental infection. Rev. Inst. Med. trop. São Paulo, 27: 111-114. 